and these two lines sordid white; t. a. line black, double, the inner portion sub-obsolete, general course nearly straight, but from the costa to median vein extending slightly inward, and from median to sub-median slightly arcuate outward, as also from sub-median to posterior margin; median shade prominent, smoky black, straight, extending from costa to posterior margin, in width .04 of an inch, a gray spot in the lower end of it, and bordered externally by the internal portion of the black annulus of the reniform, and below median venules by what seems to be a portion of the t. p. line; t. p. line obsolete save some black points between white on the veins and the arcuate black portion before spoken of, bending outward round the reniform and inward below this ; sub-terminal line whitish, irregular, faintly sending gray streaks to the margin on the veins. Stigmata large; orbicular elongate transversely to the wing, black annulate with a white shading inside this; reniform kidney-shaped with the outer depression quite prominent, a prominent black border toward base of wing, but none or only slight on the outside, inside this a white bordering that extends round the spot. Outer margin a black line, fringe concolorous with the wing. Hind wings pale smoky gray, nearly uniform, slight indication of a line through the middle, fringe whitish. Thorax gray with the shoulder tufts and posterior scales black tipped. As this covering had been slightly disturbed, could not tell whether these posterior scales formed a low tuft or not, but should think they did. Under side gray, with but faint indication of marks.

Described from two females from Soda Springs, Sishyon Co., California, one in the cabinet of James Behrens, and the other in the cabinet of G. H. French, captured in September, 1885 .

\title{
NORTH AMERICAN TACHINIDÆ.
}

\section{GONIA}

BY PROF. S. W. WILLISTON, NEW HAVEN, CT.

The genus Gonia is one easily recognized by reason of its peculiar structure of the head and antennæ; unfortunately the separation of species is a much less simple matter. As is so frequently the case, isolated speci- 
mens frequently furnish grounds for much more decided opinions than a richer material will sustain. I describe in the present paper five species that present characters sufficiently decisive to render their recognition not doubtful ; other species I forbear to name till my material is richer. It will be seen that I make little use of the structure of the arista, a character that has been relied upon much in the European species; but I am satisfied that it is a variable one in individuals of the same species, and is, moreover, distinctly sexual. There is a distinct variation in different species in the position of the anterior cross-vein, as regards the termination of the auxiliary; of how much value the character is I am not yet decided.

Generic characters.-Moderately large species, not very bristly. Head very large, inflated; front very broad, only a little narrower in the male, with numerous, not very strong bristles ; face in profile nearly perpendicular, the epistoma but slightly projecting; the oral margin with a row of bristles, not ascending on the edges of the median facial depression. Cheeks broad; bare, or with short bristles. Antenna elongate; third joint two or three times as long as the second in the female, from four to eight times in the male; arista stout, composed of three joints, the second and third elongate, and joining each other at an angle, as though broken. Eyes bare. Palpi cylindrical. Scutellum with six strong brist.es on its border. Abdomen broad oval or ovate; first and second segments each with a pair of median posterior bristles and one extreme lateral posterior one; third segment with a row on the posterior border. No spinule at tip of auxiliary vein; fourth vein obtusely angulated, without stump of vein, terminating in the costa a considerable distance before the tip ; posterior cross-vein much nearer the angle than to the anterior cross-vein.

Head yellow, except the occiput, palpi yellow; thorax black, margins of dorsum and scutellum often yellowish; legs black. Larvæ, so far as known, parasitic on hymenoptera and lepidoptera.

\section{Table of Species.}

I.-Abdomen wholly black, or at most only somewhat reddish on the sides of base ; claws and pulvilli of male small. . FRONTOSA Say.

Abdomen largely or wholly red or yellow.

2.-Face and antennæ golden yellow ; claws of male small. . sENILIs, n. sp.

Face and antennæ not golden yellow.

3.-Sides of face, pleuræ and femora with yellow hair ; claws and pulvilli of male small.................................... PORCA, $n$ sp. 
Sides of face with black bristles; pleuræ not with yellow hair. . . 4 4 4.-Abdomen reddish yellow, with or without small black spots; claws and pulvilli of male small.........................SEQUAX, n. sp.

Abdomen largely black; claws and pulvilli of male large . . ExuL, n. sp.

Gonia frontosa Say, J. Acad. Phil. vi., I 75 ; Compl. Wr. ii., 365. Gonia philadelphica Macquart, Dipt. Exot. ii., 3, 5 I, 6.

? Gonia albifrons Walker, List, etc., iv., 798.

. Length 9.5-10 m.m. Face and front light yellow, with a silvery, or slightly golden sheen; front a little translucent on the sides when seen from above ; face on the sides with short black bristles, and a number of longer ones near the sides of the median depression; median depression in its greatest width about as wide as the least width of the sides of the face; cheeks with short black bristly hairs only. Antennæ blackish brown, the second joint and base of third yellowish; second joint about one-third the length of the third; second joint of the arista not more than three-fifths the length of the third. Palpi yellow. Dorsum of thorax black; the humeri, post-alar callosities, and scutellum in large part, luteous yellowish; dorsum, when seen from behind, distinctly gray pollinose, leaving four slender stripes. Bristles of scutellum long, reaching to base of third abdominal segment. Abdomen deep shining black; the second segment with a very narrow, the third with a narrow, the fourth with a moderately broad, basal white-pollinose cross band. Wings nearly hyaline behind; the costal, subcostal and first basal cells very distinctly tinged with brown.

$\hat{o}$. Length 9-10 m.m. Front distinctly narrower, and more projecting below. Median facial depression deeper, larger, and longer, broader below than the sides of the face. Antennæ larger and longer, the second joint shorter, not more than one-fifth or one-sixth as long as the third; arista shorter than the joint, its second joint curved, three-fifths, or threefourths as long as the third. Dorsum of the thorax a little more hairy. Abdomen more elongate or egg-shaped, the sides of the second and third segments sometimes reddish. Tarsal joints of front feet a little less disciform, the claws a little longer.

This description is drawn from twelve females, mostly collected together in Fairmount Park, Philadelphia, by Mr. E. Keen, and eight males from Minnesota, collected together. They are all closely related, and their absolute identity seems certain. Among these specimens, however, 
there is no absolute uniformity in the length of the aristal joints, though not much discrepancy.

All the rest of my specimens, from various localities throughout the United States, are larger, reaching twelve and a half millimetres in length and none of them as small as the largest of the ones described. The pollinose bands of the abdomen are usually broader on the second and third segments, the wings in none so strongly infuscated proximally, and in most the infuscation is more or less obsolete; the antennæ vary from red to black, the second joint of the arista in the female varies from onethird to three-fourths as long as the third joint; in the male from one-half as long to longer. The dorsal thoracic stripes vary from very slender ones in Colorado specimens, to broader and more distinct ones in New England, North Carolina, and Southern Californian ones. Specimens from Carolina and New England have the basal part of the venter yellowish red, with moderately large spots on the sides of the basal segments above. A specimen from Wyoming has the thoracic dorsum strongly pollinose, and the bands of the abdomen unusually broad. Two others from. California have the second joint of the arista very short, not a third of the length of the third, the wings scarcely at all infuscated in front, and, unlike all the other specimens, the cheeks do not have black hairs, but yellow pile; other specimens from California, however, are like the eastern ones in this respect. Yet another, rubbed (female) specimen, from Connecticut, differs in having the sides of the face distinctly narrower, considerably narrower than the median portion. The bristly hairs on the sides of the face vary not a little in size; those of the described specimens leave a more bare space below on the inner side, that is less, or not at all, apparent in the larger specimens.

The value of these various characters I confess myself unable to decide. Only this much seems certain, no, or little reliance can be placed upon the comparative lengths of the aristal joints ; and the second joint is always longer and more bent in the male than in the female.

- I think there can be little doubt but that this is Say's species; his "large, obsolete, reddish brown spot near the base" of the abdomen is not usually, though frequently, present. The synonymy of $G$. philadelphica seems equally certain. The species must be closely allied to, possibly identical with $G$. fasciata Meigen, of Europe, the larvæ of which have been found in nests of Bombus terrestris and Megilla retrusa, where the flies deposit their eggs. A specimen from the Boston Society of 
Natural History, somewhat teneral with red antennæ, bears the label: "From Pyrrharctia isabella, Apr. 24."

Altogether, I have examined about seventy-five specimens, from New England, New York, Pennsylvania, North Carolina, Indiana, Minnesota, Montana, Colorado, Wyoming, Northern and Southern California.

Gonia SENILIS, n. sp.

t. Length $\mathrm{r} \circ \mathrm{m}, \mathrm{m}$. Front and face golden yellow, not very changeable, the vertex on either side sub-translucent when seen from above; sides of the face considerably narrower than the median depression, clothed with short black bristles. Antennæ wholly pure orange-yellow, the tip of arista brownish, second joint very short, third very long, six or eight times longer than the second; second joint of the arista shorter than the third. Thorax not densely pollinose, when seen from behind, with four slender stripes, scutellum luteous at tip only. Abdomen black, the sides broadly red, forming a moderately broad lateral posterior margin to the first and reaching to about the middle of the third segment on the sides ; pollinose bands broad. Wings nearly hyaline, anterior cross-vein nearly opposite the middle of the subcostal section of the costa. Claws and pulvilli small.

One specimen, Western Kansas. Although I have but the single specimen, I venture to describe this species. The color of the antennæ seems evidently normal ; should it really be darker in other specimens, however, the other characters given will, I believe, render the species recognizable.

Gonia PORCA, n. sp.

f. Length 13 m.m. Face and front light yellow with a silvery sheen, the front, except in a very oblique light, oily translucent on the sides; sides of the face without the usual short black bristles, except above; the largest part, as also the cheeks, is clothed with long fine hairs or pile; the usual row along the sides of the median depression. Median depression wider than the sides of the face below. Antennæ black, the third joint five or six times longer than the second; second joint of the arista shorter than the third. Dorsum of thorax thinly pollinose, stripes not very distinct; the sides more or less and the scutellum luteous yellow. Pleuræ with long fine yellow hairs or pile. Abdomen yellowish red, shining; pollinose bands narrow, that on the second very 
narrow; first segment, under the scutellum, the second with a median stripe, the third with a stripe more or less dilated behind, and the fourth chiefly, black. The anterior femora behind with long fine light yellow hair. Wings nearly hyaline, the costal cells scarcely infuscated.

Two specimens, Mt. Hood, Or. The moderately abundant, long, light yellow fine hair on face, pleuræ and four anterior femora is characteristic.

Gonia ExUL, n. sp.

․ Length $12,13 \mathrm{~m} . \mathrm{m}$. Front and face light yellow, with a semitranslucent appearance as though oiled; when seen obliquely, with a silvery sheen; sides of the face with numerous, short, black bristles, on the inner part, near the sides of the median depression, with three or four moderately stout bristles; median depression small and narrow, not as wide as the sides; cheeks without black bristles. Antennæ blackish brown, second joint and base of third yellow; second joint about onethird the length of the third; arista variable, third joint not twice the length of the second. Dorsum of thorax gray pollinose, when seen from behind leaving four moderately broad stripes, the margins more or less and the scutellum yellow. Abdomen yellowish red; first segment under the scutellum, the second with a broad median stripe, the third except the anterior angles, or, rather, with a large triangle reaching the whole width of the segment behind and touching in front more or less broadly, the dorsum of the fourth wholly black; pollen of the whole abdomen variable in different reflections, but most conspicuous on the base of the third and the whole of the fourth segments. Wings nearly hyaline, the veins yellowish, except posteriorly.

Ten specimens, Connecticut, Massachusetts, New York.

a. Males from California, that I cannot distinguish, have the antennæ wholly black, the third joint five or six times the length of the second, the face strongly silvery pollinose, and the claws and pulvilli very large, considerably longer than the terminal joint of the tarsi. In some, the black triangle on the third abdominal segment is much smaller. A female with them seems to agree in all respects with the Eastern specimens.

$b$. A female specimen from California, with the abdomen marked similarly, has the third joint of the antennæx shorter, not more than twice the length of the second, the second joint of the arista very short, and the bristles on the sides of the median depression not parallel with the edge, but divergent, whisker-like. 
c. Two female specimens from Arizona differ distinctly in having a broader and more projecting face, smaller eyes, whiter and more dense pollen on face, thorax and abdomen. Another specimen with these two, however, though agreeing in the latter respects, has the face of the usual width.

d. A male specimen from North Park is of a distinct species, though closest allied to the present. The sides of the face are unusually narrow, the front short, convex and almost horizontal, the abdomen marked more like that of $G$. senilis, the size smaller (I I m.m.), the claws and pulvilli large.

Gonia SEQuax, n. sp.

d. Length I2-I3 m.m. Like the males of exul, except that the abdomen is either wholly yellowish red, with a black spot under the scutellum, and a brownish hind margin to the third segment, or with a slender black stripe on the second, and a small triangle on the third and fourth segments. The claws and pulvilli are very much smaller, much shorter than the terminal joints of the tarsi.

Three specimens, California.

\section{NOTES ON THE GENUS EXOPROSOPA.}

BY D. W. COQUILLETT, LOS ANGELES, CAL.

In my paper on "The North American Genera of Anthracina," which appeared in the last volume of the Can. Entomologist (pp. I $57-159$ ), I proposed the name Velocia for those species of Exoprosopa which have four submarginal cells in each wing. Through the kindness of Dr. Williston, I have been put in possession of a paper by Prof. Camillo Rondani, entitled "Dipterorum Species et Genera Aliqua Exotica," published in I 863 in the Archivio per la Zoologia, vol. iii., and on pages $5^{6}$ and 57 of this paper Prof. Rondani proposes the name Hyperalonia for the above group; this name being the earlier, must supersede the one proposed by me.

In the same paper Prof. Rondani proposes the name Argyrospila for those species of Exoprosopa in which the third and fourth veins are joined together before the margin of the wing, instead of reaching the margin 